\title{
CHILD DEVELOPMENT IN BALIKPAPAN CITY AS THE EFFECT OF URBANIZATION
}

\author{
Herry Fernandes Butar Butar \\ Department of Correctional Guidance \\ Polytechnic of Correctional Science, Depok \\ East Java, Indonesia
}

\begin{abstract}
Changes in Indonesian public policy especially in handling people's spread to another area resulting in people's desire to move to another area that have the potential place to become their source of income in order to support their family life. Problem arose when their hopes to get a better life did not accomplished so the family cannot have the better live. The phenomenon of street hawkers in city of Balikpapan is one of bad fact that happened because the parents cannot fulfill their children's needs. Another thing is they did not have civil record, so it is hard for the children and parents to get medical insurance in order to have the access on medical. This research is aiming to develop and explain the problems of street hawkers in city of Balikpapan that must be working and getting into the bad environment. Methods that being used is deep interview with relation institution such as Social Institutions also Women Empowerment, and Children Protection Institution whereas the problems being solved by them with coordination from civil society. It concludes that the phenomenon affects children's development that should be able to enjoy life properly.
\end{abstract}

Keywords - Street Hawkers, Child Development, Urbanizations

\section{INTRODUCTION}

In year of 2017, the city of Balikpapan already got the achievement of "Madya" in the City Fit for Children programs coming from the Ministry of Women Empowerments and Child Protection. The reward was so in doubts since still we can find street hawkers in the city or underage workers working in dangerous conditions, mostly selling newspaper in the street. Most of the underage workers in Balikpapan are still studying in schools and already dropout from the education. They are doing it because of many reasons, some of them wants to add their money, some of them wants to help their families or just following their friends (Susanti, 2013). The problem on children development in Indonesia is caused by the level of poverty shows in data that Statistics Indonesia BPS) published on 2015. There are $11.13 \%$ from total of population still lived in poverty (Fajriah, 2016). The rate of urbanization in Indonesia that still occurring to this day also one of the factors on how the children developing in life. The current urbanizations are

\author{
Muhammad Ali Equatora \\ Department of Correctional Guidance \\ Polytechnic of Correctional Science, Depok, \\ East Java, Indonesia
}

shifting from the movement of the prosperity in rural area to urban are now becoming the movement of the poverty in rural area to urban area (Mutmainnah, Kolopaking, \& Wahyuni, 2014). The city of Balikpapan has its own specialty, known as the oil city and the gate of Borneo, many peoples believe this is the right place to have a good life. Balikpapan also has the similarity with Jakarta, which its people coming from different ethnicity and there is no significance dominance of one of the ethnic. The children development mostly affected by the income rate of their parents, there is a higher possibility that children who live in poverty will not be able to get enough nutrition and enough education in order to compete in the future. This study intends to get clear conception about the relation of urbanization and children development.

Graph 1. Total Population in Balikpapan on Year $2001-2011$

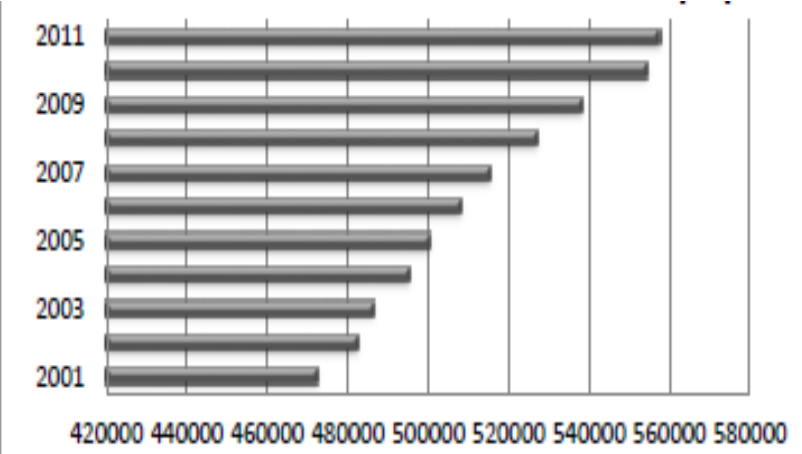

Source: (Mutmainnah, Kolopaking, \& Wahyuni, 2014)

\section{METHODOLOGY}

\section{A. METHODS}

This research is using qualitative methods through in-depth interview with officials at Balikpapan's Official Social Agency and Child Protection Agency. Primary data that being used in this research coming from depth interview and the secondary source utilizing governments documents also articles that related with the topics of the research. The writing describe fully on the children development in Balikpapan with the explanation of urbanization might affect the situation on child development. The research took place on February until March in Balikpapan. Balikpapan is chosen to become the place of this 
research because its current status on programs "Kota Layak Anak" category "Madya" but in the reality a few children still living in a bad environment and also working in street. This research relies heavily on the depth interview between officials without interviewing the children so the study will be a critic of existing government rules towards the children development. This research using criminology perspective and children development framework to counter current situation in Balikpapan why urbanization and child development has a similar relation and affecting each other. The data that collected in this research is official and given by the official sources and using only articles published last 10 years. The official sources chosen because their responsibility in children development in Balikpapan and the programs of "Kota Layak Anak".

\section{B. THEORIES AND CONCEPTS}

This research used social welfare criminology theory that focused on the social welfare factor in the family that became the problems to children development. Social welfare is the purpose of nation's independence that related to the crime concepts. The purpose of social welfare is to provide goods and special service to people and families that have rights to receive service.

There are 4 principals in order social control programs must be execute such as: (Mustofa, 2010)

a. Regulations about citizens' rights and obligations;

b. Continuous Socializations about regulations;

c. Facilitation to every citizen to obey the regulations;

d. Application of sanctions if offense occurred.

These are the tools that used in this research to explain about the phenomenon of child development in Balikpapan especially when urbanizations program that happened in the past until now effect the development of children.

\section{EXPERIMENT AND RESULT}

Based on the data from Integrated Service Centre of Women and Children Empowerment of Balikpapan, there is total of 33 cases of violence against children on 2015 and rose to 80 cases in 2016, and in year 2017 registered about 112 violence cases. Most of the violence are recorded to be sexual violence's (Ombudsman, 2018). One of the key officials in Women Empowerment, Children Protection, and Keluarga Berencana Agency (DP3AKB) believes the number rising after they held socialization to every household in each area, so some of the people or children do not afraid to inform that such violence happened and admit in became victims.

\begin{tabular}{|c|c|c|c|c|c|c|c|c|}
\hline \multirow[t]{2}{*}{$\mathrm{N}$} & \multirow[t]{2}{*}{ Objective } & \multirow[t]{2}{*}{ Goal } & \multirow{2}{*}{$\begin{array}{l}\text { Indicat } \\
\text { or of } \\
\text { Works }\end{array}$} & \multirow[t]{2}{*}{ Unit } & \multicolumn{2}{|c|}{ Target } & \multicolumn{2}{|c|}{ Realization } \\
\hline & & & & & 2015 & 2016 & 2015 & 2016 \\
\hline 1 & $\begin{array}{l}\text { Increasi } \\
\text { ng the } \\
\text { service } \\
\text { and } \\
\text { protectio } \\
\text { n of } \\
\text { Family } \\
\text { with } \\
\text { Poverty } \\
\text { Problem } \\
\text { s }\end{array}$ & $\begin{array}{l}\text { Effective } \\
\text { ness of } \\
\text { the } \\
\text { service } \\
\text { and } \\
\text { protectio } \\
\text { n }\end{array}$ & $\begin{array}{l}\text { Numb } \\
\text { er of } \\
\text { the } \\
\text { family } \\
\text { being } \\
\text { helped }\end{array}$ & $\%$ & 20 & 20 & 16.79 & 8.91 \\
\hline
\end{tabular}

Table 1. Employment and Social Agency of Balikpapan Activity on Family

Source: Performance reports of Balikpapan Social Agency, (Balikpapan, 2016)

On year 2015, Balikpapan Social Agency planned to divide the agency into two entity, focusing on each specialty because of the workload of its agency then finally in 2016, Balikpapan has its own Social Agency and Employment Agency. On the table above showed the realization in 2016 far from achieved the target, it happened because the limitations of human resource capable of doing the works. Ms. Noora, officials from Social Agency confirmed that some programs cannot work efficiently that there is a challenging problem of limited expert in the team. The Agency works closely with other civil society to overcome problem in family with prosperity problems. Some of the children in those families that came to Balikpapan from other city or rural areas.

Table.2 Interview Result Social Agency Service for Children with Social Problem Welfare in 2017

Source: Interview result (Noora, 2018)

\begin{tabular}{|c|c|c|}
\hline No & Data & Total \\
\hline \multirow[t]{5}{*}{1.} & Child having Legal Issues & 73 \\
\hline & Accompaniment & 56 \\
\hline & Guiding at Protection House & 8 \\
\hline & $\begin{array}{l}\text { - } \quad \text { Distributed to Samarinda Agency } \\
\text { Samarinda }\end{array}$ & 3 \\
\hline & $\begin{array}{l}\text { - } \text { Compulsory work and Compulsory } \\
\text { reporting to Balikpapan Social Agency } \\
\text { after undergoing sentence at Balikpapan } \\
\text { Class II Prison }\end{array}$ & 6 \\
\hline 2. & Childs needs Special Protection & 5 \\
\hline 3. & Adopted Children & 11 \\
\hline 4. & Victims of Violence & 3 \\
\hline 5. & Victims of Drugs abuse & 11 \\
\hline 6. & Punk Children & 15 \\
\hline 7. & Neglected toddler & 5 \\
\hline 8. & $\begin{array}{l}\text { Neglected Children on development process at } \\
\text { Social Welfare Agency }\end{array}$ & 957 \\
\hline 9. & Beneficiaries of elderly social assistance & 97 \\
\hline 10 & Home Visit Neglected Elderly & 9 \\
\hline 11 & $\begin{array}{l}\text { Elderly that been developed in Social Welfare } \\
\text { Agency for Elderly }\end{array}$ & 21 \\
\hline 12 & Elderly Home Care & 30 \\
\hline \multirow[t]{5}{*}{13} & Street Children on Talented Activities & 200 \\
\hline & $\begin{array}{l}\text { - } \quad \text { The community of Indonesian Child's } \\
\text { Education (KOPPAJA) }\end{array}$ & 55 \\
\hline & - $\quad$ Public School & 45 \\
\hline & - $\quad$ Nurul Ilmi Agency & 40 \\
\hline & - $\quad$ Care for Indonesian Successor & 60 \\
\hline
\end{tabular}

There were some programs that Social Agency collaborating with other agency such DP3AKB or civil societies to enhance the life of poor families in Balikpapan, because some of the 


\section{International Journal of Engineering Applied Sciences and Technology, 2020 Vol. 4, Issue 9, ISSN No. 2455-2143, Pages 409-412 \\ Published Online January 2020 in IJEAST (http://www.ijeast.com)}

problem in children development lies in the families. Some of the street hawkers that found on the street of Balikpapan usually will be carried by Pamong Praja Police to be investigated about their home and the family, if they do not have family, the social agency will take care of them. In order to challenge the problem in poor families, social agency gave the parents the skills in order they can open their own business or working in the formal industry.

In Welfare Criminology perspective, the problems of children development can be tackled with focusing on the effective use of socialization, counseling, or accompany child and parents to know the depth of the problems occurs and relate to the urbanization that happened. Since the culture of the city and the migrant families outside province might be different, such socialization and understanding of the regulation can be determine the life of families. As in Indonesia, Statistic Centre of Balikpapan shows it projection that the population in 2018 rose from 636.012 to 645.727 peoples. (Badan Pusat Statistik Kota Balikpapan, 2019). There are three factors affecting the rise of population in cities such as people's migration from rural area to urban area, the rise of birth rate, and reclassification of rural becoming urban as the result of development (Chotib, 2008). Some of the problems occurs in the family also occurs when the father goes to other city to work and left his wife and children, the long distance relationship affect the intensity of conflict between husband and wife then suddenly can affect the behavior problems of children (Herawati \& Endah, 2016)

Children's must have basic nutrition, survival, cognitive and socioemotional interactions, reduction of abuse and violence, and support for quality and optimal proximal environments that should be reflected on the national policies (Britto \& Ulkuer, 2012). These criteria poured in the framework of Kota Layak Anak programs that currently Balikpapan tried to implement and to fulfill the child rights as well ensuring survival and physical health of children (Bornstein, et al., 2012). The number of violence's that shown in the result section only known if the society actively participate and aware of the event that happened. These are the key point of having an effective socialization to every household about the importance of children life. Case happens in children development after moving from rural to urban area especially they are coming from poor background is the access to get identification card (KTP). Nowadays, these documents such birth certificate very important to have which is will be used to register medical insurance (BPJS).

The problems of child development can be described as everybody responsibilities that needs to be classified as special case. Welfare criminology that focus on social welfare suggests that the changes can be done by strengthen the regulation, then socialization of the regulation, facilitation of communities to run children protection program, and giving sanctions to every offender. These subjects can be judged by the information of regulation that been accepted by the communities and participation rate in socialization activity. The Facilitation process focus more to the function that given by the government agency and ensure the people can use the facilitation effectively and efficiently. The sanctions part is the last resort of action that needs to be done but still it needs to reconciliate, so every stakeholder understands that the sanction that been given is professionally given. Reconciliation must be done properly because sometimes the offender did not know thoroughly about the regulation of child protection which why the socialization activity played important role to ensure every stakeholder get the information of children protection regulations.

\section{CONCLUSION}

Urbanization happened in Balikpapan is one of examples peoples migrating from rural areas to urban areas in order to get better life. Poor families that come to the city to get better life have to face reality that the prosperity cannot come easily then decided to send their children to join the workforce which will disrupt their development and the possibility of being exposed to dangerous situation. Children developments especially for street hawkers that do not have parents is hard to get the identification card which is important to register such as medical insurance and get civil rights. This is the area that local government in Balikpapan to help and assisting them have the access and fulfill their civil rights. Socialization and accompaniment program must do effectively coordinating with civil society and other agency in order to help society understand the notable of children developments. The socialization of regulation needs to be done effectively since the people coming to another area does not know the other city regulation.

\section{REFERENCE}

[1] Badan Pusat Statistik Kota Balikpapan. (2019, May 16). Proyeksi Penduduk Kota Balikpapan Menurut Kecamatan Tahun 2010-2018. Retrieved from Statistics Balikpapan: https://balikpapankota.bps.go.id/statictable/2018/01/19/5 4/proyeksi-penduduk-kota-balikpapan-menurutkecamatan-tahun-2010-2017.html

[2] Balikpapan, P. K. (2016). Laporan Kinerja Instansi Pemerintah Kota Balikpapan. Balikpapan: Balikpapan Government.

[3] Bornstein, M. H., Britto, P. R., Nonoyama-Tarumi, Y., Ota, Y., Petrovic, O., \& Putnick, D. L. (2012). Child Development in Developing Countries: Introduction and Methods. Child Development Journal, 83(1), 16-31. doi:https://doi.org/10.1111/j.1467-8624.2011.01671.x

[4] Britto, P. R., \& Ulkuer, N. (2012). Child Development in Developing Countries: Child Rights and Policy Implications. Child Development Journal, 83(1), 92-103. doi:https://doi.org/10.1111/j.1467-8624.2011.01672.x 
[5] Chotib. (2008). Urbanisasi dan Migrasi di Kota Depok, Jawa Barat. Warta Demografi, 38(1), 7-16.

[6] Fajriah, L. R. (2016, January 4). Angka Kemiskinan Meningkat Tembus 28,51 Juta Orang. Jakarta.

[7] Herawati, T., \& Endah, N. Y. (2016). The Effect of Family Function and Conflict on Family Subjective Well-being with Migrant Husband. Journal of Family Sciences, 1-12. doi:https://doi.org/10.29244/jfs.1.2.1-12

[8] Mustofa, M. (2010). Kriminologi: Kajian Sosiologi Terhadap Kriminalitas, Perilaku Menyimpang dan Pelanggaran Hukum (2nd ed.). Bekasi: Sari Ilmu Pratama (SIP).

[9] Mutmainnah, A., Kolopaking, L. M., \& Wahyuni, E. S. (2014, Juli). Urbanisasi di Kota Balikpapan: Formasi Sosial Keluarga Pendatang Miskin. Jurnal Ilmu Sosial dan Ilmu Politik, 18(1), 51-65. Retrieved from https://journal.ugm.ac.id/jsp/article/view/13098/9328

[10] Noora. (2018, Februari). Social Agency Services for Children with Social Welfare Problem. (H. F. Butar, Interviewer)

[11] Ombudsman. (2018, February 23). Kabar Perwakilan. Retrieved from Ombudsman Republik Indonesia: https://ombudsman.go.id/perwakilan/news/r/pwk-kekerasan-seksual-mendominasi

[12] Susanti, E. (2013, Juni). Upaya Pencegahan Terhadap Pekerja Anak di Kota Balikpapan. Jurnal Risalah Hukum, 9(1), 25-38. 